\title{
PENGEMBANGAN MATERI FIKIH KELAS VIII MADRASAH TSANAWIYAH: TENTANG INDAHNYA BERPUASA
}

\author{
Abdul Karim Khoirul Huda \\ maskarim007@gmail.com \\ UIN Sunan Kalijaga Yogyakarta
}

\begin{abstract}
This article aims to find out anything in the depth and breadth of the fasting material in class VIII Madrasah Tsanawiyah. The method used in this research is literature study, data collected through student books and fikih class VIII Madrasah Tsanawiyah teacher books, as well as treatment with the results of previous studies related to material development, then analyzed and described. The results of this study indicate that the subject matter contained in the eighth grade students' printed books of the subjects in the fasting chapter is still not broad and deep, so that teachers are expected to develop material that will apply it by paying attention to the requirements for developing, namely, facts, concepts, principles. , and procedures, then the four conditions must have the following things, namely distinctive, functional, valuable, and easy to use. This is an alarm so that students do not stutter about the development of science and technology and are able to keep up with the religious knowledge that has been learned. The expected positive impact of research activities by revising and developing fiqh subject matter, namely fiqh material is different from the previous one, it is more weighty, functional and easy to apply for teachers and students.
\end{abstract}

\section{Keywords: Development, Material, fiqh, MTs}

\begin{abstract}
Abstrak
Artikel ini bertujuan untuk mengetahui seberapa dalam dan luas materi puasa yang diajarkan pada kelas VIII Madrasah Tsanawiyah. Metode yang digunakan dalam penelitian ini adalah studi pustaka, data dikumpulkan melalui buku siswa dan buku guru pelajaran fikih kelas VIII Madrasah Tsanawiyah, serta dikaitkan dengan hasil penelitian-penelitian terdahulu yang berkaitan dengan pengembangan materi, data kemudian dianalisis dan paparkan. Hasil penelitian ini menunjukan bahwa materi pelajaran yang
\end{abstract}


terdapat dalam buku cetak siswa kelas VIII mata pelajaran fikih pada bab puasa masih kurang luas dan mendalam, sehingga guru diharapkan dapat melakukan pengembangan materi yang akan diajarkannya dengan memperhatikan syarat-syarat melakukan pengembangan yaitu, fakta, konsep, prinsip, dan prosedur, kemudian keempat syarat tersebut harus memiliki hal-hal berikut, yaitu distingtif, fungsinal, bernilai, dan mudah digunakan. Hal ini dimaksudkan agar para siswa tidak gagap terhadap perkembangan IPTEK dan mampu mengimbanginya dengan ilmu agama yang telah dipelajari. Dampak positif yang diharapkan dari kegiatan penelitian dengan melakukan perevisian dan pengembangan materi pelajaran fiqih ialah materi fiqih berbeda dari yang sebelumnya, semakin berbobot, fungsional dan mudah untuk dipahami bagi guru maupun siswa.

\section{Kata Kunci: Pengembangan, Materi, Fikih, MTs}

\section{A. Pendahuluan}

Belajar sepatutnya adalah yang penting-penting dulu, apabila masih memiliki waktu yang tersisa tentunya boleh untunk belajar yang kurang penting atau belajar yang lain. Tujuan seseorang belajar adalah untuk menguasai materi pelajarannya serta untuk lolos dalam ujian akhir, ulangan harian, dan kuis. ${ }^{1}$ Kata belajar sudah sering terdengar di setiap kuping masyarakat. Hanya saja pengertian belajar yang mereka pahami mungkin berbeda-beda, para ahli juga sepertinya berbeda dalam mengartikan kata belajar. Afi Parnawi mengutip pendapat dari Cronbach bahwa learning is shown by change in behavior as a result of experience. Belajar sebagai sebuah kegiatan yang ditunjukan oleh perubahan tingkah laku sebagai hasil dari pengalaman. Selanjutnya Howard L. Kingskey mendefinisikan learning is which behavior (in the broader sence) is originated or changed through practice or training. Belajar ialah proses dimana tingkah laku (dalam arti luas) ditimbulkan atau diubah lewat praktek atau latihan. ${ }^{2}$

Belajar yang dilakukan seorang siswa sangat dipengaruhi oleh campur tangan seorang guru dan juga materi yang diajarkan. Materi yang

1 Sutanto Windura, Shortcut to genius: (belajar lebih sedikit, tahu lebih banyak, dan bebas stres!) (Jakarta: PT Gramedia, 2013), hal 87-88.

2 Afi Parnawi, Psikologi Belajar (Sleman: Deepublish, 2019), hal 1. 
diajarkan kepada siswa biasanya sudah berbentuk buku paket, sehingganya guru tinggal menjelaskan dan mengajarkan sesuai dengan buku paket yang digunakan. Buku paket atau bahan ajar cetak telah dirancang dan didesain agar menambah minat siswa untuk membaca. Namun pada kenyataanya keberadaan buku-buku tersebut tidak menambah minat siswa untuk membaca atau belajar. ${ }^{3}$ Hal semacam ini bisa saja di karenakan materi yang disajikan dalam buku cetak kurang menarik, atau penyajiannya yang terlalu rumit dan susah untuk dipahami. Disinilah perlunya campur tangan seorang guru, guru hadir untuk mengembangkan materi tersebut agar menjadi mudah untuk dipahami siswa.

Materi pembelajaran ialah materi yang dipakai untuk mencapai tujuan pembelajaran, ${ }^{4}$ materi pembelajaran berupa pengetahuan, keterampilan, serta sikap yang perlu dikuasai oleh siswa untuk memenuhi standar kompetensi yang ditetapkan. Isdisusilo yang dikutip oleh Churri dan Agung menjelaskan bahwa materi yang ditetapkan dalam kegiatan pembelajaran harus benar-benar menunjang untuk tercapainya standar kompetensi, dan kompetensi dasar, serta tercapainya sebuah indikator. ${ }^{5}$ Untuk mencapai hal tersebut, siswa tidak bisa mencapainya secara sendirian, apalagi hanya berdasarkan buku paket atau bahan ajar seadanya. Sudah menjadi tugas seorang guru untuk mengembangkan materi pembelajaran yang menjadi tanggung jawabnya, hal tersebut dimaksudkan agar apa yang menjadi tujuan pendidikan nasional dapat tercapai.

Tujuan pendidikan nasional itu sendiri seperti yang tertulis dalam Undang-Undang no 20 tahun 2003 pasal 3 “Pendidikan nasional berfungsi mengembangkan kemampuan dan membentuk watak serta peradaban bangsa yang bermatabat dalam rangka mencerdaskan kehidupan bangsa, bertujuan

3 Ermaniatu. N Taufik M, "Pengembangan Bahan Ajar Cetak Berbasis Penilaian Kinerja Sebagai Sumber Belajar Bagi Siswa SD Kelas Vi,” School Education Journal Pgsd Fip Unimed 7, no. 3 (20 Juni 2017): hal 285-286, https://doi.org/10.24114/sejpgsd.v7i3.9251.

4 Andi Prastowo, Menyusun Rencana Pelaksanaan Pembelajaran (Rpp) Tematik Terpadu Implementasi Kurikulum 2013 Untuk Sd/Mi, cetakan ke-2 (Jakarta: Kencana, 2017), hal 194.

5 Mohamad Ainul Churri dan Yudha Anggana Agung, "Pengembangan Materi Dan Media Pembelajaran Mata Pelajaran Dasar Kompetensi Kejuruan Teknik Audio Video Untuk Smk Negeri 7 Surabaya” 2 (2013): hal 804. 
untuk berkembangnya potensi peserta didik agar menjadi manusia yang beriman dan bertaqwa kepata Tuhan Yang Maha Esa, berakhlak mulia, sehat, berilmu, cakap, kreatif, mandiri, dan menjadi warga negara yang demokratis dan bertanggung jawab”. Berakhlak mulia, sehat, kreatif, dan sebagainya seperti yang disebutkan dalam pasal 3 diatas merupakan bagian dari karakter yang ingin dicapai dalam pendidikan nasional. Salah satu upaya untuk mengembangkan karakter adalah lewat pendidikan agama islam.

Pendidikan Islam pada sekolah umum baik SD, SMP, dan SMA telah dikemas menjadi satu yakni PAI dan Budi Pekerti dengan terdiri dari beberapa mata pelajaran yang diajarkan di sekolah Islam yaitu Akidah akhlak, fikih, Al-qur'an Hadis, dan SKI. ${ }^{6}$ Pada sekolah Islam atau madrasah materi Pendidikan Agama islam telah di pisah-pisah sebagai mana disebutkan diatas, dengan maksud agar siswa di madrasah lebih mendalami ajaran Agama Islam. Pelajaran tentang sholat, puasa, zakat, bersuci, dan lain sebagainya adalah berkaitan dengan ibadah wajib umat islam, yang semuanya itu masuk dalam mata pelajaran fikih. Pembelajaran fikih bertujuan untuk menuntun siswa memahami pokok-pokok hukum islam serta tata cara pelaksanaan agar dapat diaplikasikan dalam keseharian, sehingga menjadi seorang muslim yang menjalambkan ajaran agama Islam secara kaffah (sempurna). ${ }^{7}$

Melihat betapa pentingnya pelajaran fikih dan materi-materi didalamnya perlu benar-benar dipahami oleh para siswa agar dapat menjadi bekal hidup mereka, maka pengembangan materi dalam pelajaran fikih adalah sesuatu yang perlu dilakukan. Penulis memilih materi tengtang puasa pada kelas VIII Madrasah Tsanawiyah untuk dikembangkan guna memenuhi kebutuhan siswa dan mudah dalam penerapannya. Serta nantinya dapat digunakan sebagai pertimbangan para guru dalam mengajar ataupun dalam pengembangan materi yang akan mereka lakukan.

6 Sutrisno dan Muhyidin Albarobis, Pendidikan Islam Berbasis Problem Sosial (Yogyakarta: Ar-Ruzz Media, 2012), hal 52.

7 Susandi, "Pengembangan Bahan Ajar Fiqih Berbasis Multimedia Menggunakan Aplikasi Autiplay Studio 8,” Jurnal Penelitian Ipteks volume 4, no. 2 (2019): hal 242. 


\section{B. Pembahasan}

\section{Kajian Teori}

Istilah pengembangan yang dipakai dalam proses pembelajaran sering dikaitkan dengan penelitian pengembangan, menurut Wayan Ardana hal ini maksudnya adalah untuk menjembatani antara pendidikan dengan praktik pendidikan. ${ }^{8}$ Pengembangan dapat dikatakan sebagai sebuah usaha yang dilakukan sebagai upaya perbaikan dan pengoptimalan sesuatu yang dirasa belum mampu memberikan hasil sesuai dengan tujuan yang ingin dicapai, atau untuk menyesuaikan tuntutan ilmu pengetahuan di era modern. Pengembangan mencakup segala hal yang dirasa perlu untuk dikembangkan, terutama yang berkaitan dengan ilmu pengetahuan di masyarakat, keluarga, dan sekolah (materi pelajaran, strategi mengajar, metode, dan sebagainya).

Materi Pempelajaran akan lebih baik apabila dipilih dengan memperhatikan kemapuan, minat dan bakat atau dapat dikatakan dengan memperhatikan perbedaan dan keragaman siswa. ${ }^{9}$ Identtifikasi kompetensi dasar adalah sebuah langkah pertama yang perlu dilakukan guru apabila akan melakuan pengembanga Rencana Kegiatan Harian (RKH) dan materi pembelajaran. dalam satu materi pembelajaran dengan cakupan luas bisa memiliki lebih dari satu kompetensi dasar. Sehingga mesti ditetapkan juga fokus kompetensi yang diinginkan dari siswa sebagai hasil akhir pembelajaran. kompetensi dasar juga yang dijadikan guru sebagai pedoman dalam menentukan materi pembelajaran dan juga metode yang akan digunakan. $^{10}$

\section{Metode Penelitian}

Metode yang digunakan dalam penelitian ini adalah studi pustaka, data dikumpulkan melalui buku siswa dan buku guru untuk mata pelajaran fikih kelas VIII Madrasah Tsanawiyah dan juga buku-buku lain yang mendukung,

8 M Natsir, "Pengembangan Pembelajaran Fikih Kelas X Madrasah Aliyah Dalam Model Dick \& Carey,” Jurnal Pendidikan Agama Islam (Journal of Islamic Education Studies) 5, no. 1 (2 November 2017): hal 49, https://doi.org/10.15642/jpai.2017.5.1.44-67.

9 Basuki, Pengembangan Model Pembelajaran Membaca Dengan Pelabelan Objek Sekitar (POS) Untuk Murid Taman Kanak-kanak (Sleman: Deepublish, 2015), hal 11.

10 Basuki, hal 187. 
serta dikaitkan dengan hasil penelitian-penelitian terdahulu yang berkaitan dengan pengembangan materi. data kemudian dianalisis dan paparkan kedalam bentuk tulisan.

\section{Hasil Penelitian Dan Pembahasan}

a. Analisis Kompetensi Dasar Materi Ibadah Puasa.

\begin{tabular}{l|c}
\hline \multicolumn{1}{c|}{ Standar Kompetensi } & Kompetensi Dasar $^{\mathbf{1 1}}$ \\
\hline $\begin{array}{l}\text { Indahnya bepuasa, badan } \\
\text { menjadi sehat serta memiliki } \\
\text { sikap jujur, disiplin, dan taat }\end{array}$ & $\begin{array}{c}1.3 \text { Menghayati hikmah ibadah puasa agar } \\
\text { terbiasa menjalankan ibadah puasa }\end{array}$ \\
\cline { 2 - 2 } dengan berpuasa. & $\begin{array}{c}2.3 \text { Memiliki sikap simpati dan empati } \\
\text { sebagai ipmlementasi atas } \\
\text { pemahaman menganai hikmah } \\
\text { berpuasa }\end{array}$ \\
\cline { 2 - 2 } & \begin{tabular}{l}
3.3 Menganalisis ketentuan ibadah puasa \\
\cline { 2 - 2 }
\end{tabular} \\
& $\begin{array}{l}\text { menjalankan ibadah puasa } \\
\text { mensimulasikan tata cara }\end{array}$ \\
\hline
\end{tabular}

Kompetensi dasar yang disuguhkan dalam buku cetak masihlah sangat umum. Materi apa ynag akan diajarkan oleh guru dapat kita ketahui dengan melihat kompetensi dasarnya. Hal tersebut sangat membantu guru dalam menyiapkan materi yang akan di ajarkan. Bagi guru yang mengharapkan hasil lebih baik untuk para siswanya, pastinya akan mempersiapkan materi dengan sebaik-baiknya, serta akan mengembangkan materi menjadi lebih meluas. Namun pada banyak kejadian dilapangan hanya sedikit guru yang melakukan pengembangan materi. Para guru biasanya hanya mengandalkan materi yang sudah ada dalam buku cetak dengan berpatokan pada capaian yang ada dalam buku pegangan guru.

Pengembanagan materi sangat bergantung pada seberapa jauh tujuan pembelajaran yang ingin dicapai. Pengembangan materi berkaitan dengan dua aspek yang sangat mendasar yaitu keluasan atau ruang lingkup bahan ajar dan

11 Kementrian Agama, Buku Guru, Fikih Madrasah Tsanawiyah VIII (Jakarta: Direktorat Pendidikan Madrasah Direktorat Jenderal Pendidikan Islam Kementerian Agama Republik 
tingkatan bahan ajar. ${ }^{12}$ Bahan ajar ialah bahan-bahan yang digunakan atau materi pelajaran yang telah disusun sedemikian rupa, yang digunakan guru dan siswa pada proses pembelajaran.. ${ }^{13}$ Guru memiliki wewenangng untuk mengembangkan materi atau kompetensi dasar untuk memudahkannya dalam melakukan pembelajaran atau penyampaian materi pada siswa. Pada pelajaran fikih Madrasah Tsanawiyah kelas VIII tentang puasa, memiliki standar kompetensi "Indahnya bepuasa, badan menjadi sehat serta memiliki sikap jujur, disiplin, dan taat dengan berpuasa”. Masih perlu dilakukan pengembangan oleh guru agar materinya lebih dalam, luas, dan mudah dipahami.

Pada kompetensi dasar yang disajikan dalam buku cetak, yaitu pertama, Menghayati hikmah ibadah puasa agar terbiasa menjalankan ibadah puasa. Poin ini masuk dalam KI 1 yaitu kompetensi yang berhubungan dengan spiritual. Tujuan yang ingin di capai pada KI 1 yaitu berkaitan dengan menghargai dan menghayati ajaran agama yang dianutnya. Kedua, Memiliki sikap simpati dan empati sebagai implementasi atas pemahaman menganai hikmah berpuasa. Yang kedua ini masuk kedalam KI 2 yang berkaitan dengan sikap yang ditunjukan setelah pembelajaran. Ketiga, Menganalisis ketentuan ibadah puasa. Pada bagian ketiga ini masuk dalam KI 3 yang berkaitan tentang pengetahuan yang diperoleh yaitu Memahami pengetahuan (faktual, konseptual, dan prosedural) berdasarkan rasa ingin tahunya tentang ilmu pengetahuan, teknologi, seni, budaya terkait fenomena dan kejadian yang tampak oleh mata. Keempat, Mensimulasikan tata cara menjalankan ibadah puasa. Dapat mensimulasikan tata cara iabadah puasa adah termasuk bagian keterampilan, bagian ini masuk dalam KI 4.

Mengidentifikasi aspek-aspe yang terdapat dalam KI-KD yang menjadi acuan untuk atau rujukan pengembangan materi pembelajaran

Indonesia, 2015), hal 46.

12 Muhammad Zain, "Pengembangan Strategi Pembelajaran Dan Pemilihan Bahan Ajar," Inspiratif Pendidikan 6, no. 1 (1 Juni 2017): hal 177, https://doi.org/10.24252/ip.v6i1.4925.

13 Henry Januar Saputra dan Nur Isti Faizah, "Pengembangan Bahan Ajar Untuk Menumbuhkan Nilai Karakter Peduli Lingkungan Pada Siswa Kelas Iv Sekolah Dasar,” Profesi Pendidikan Dasar 1, no. 1 (8 Januari 2018): hal 71, https://doi.org/10.23917/ppd.v1i1.3956. 


\begin{tabular}{l|l|l}
\hline No & \multicolumn{1}{|c|}{ Kompetensi Inti ${ }^{\mathbf{1 4}}$} & Aspek \\
\hline KI 1 & $\begin{array}{l}\text { Menghargai dan menghayati ajaran } \\
\text { agama yang dianutnya }\end{array}$ & Spiritual \\
\hline KI 2 & $\begin{array}{l}\text { Menghargai, dan menghayati prilaku } \\
\text { jujur, disiplin, tanggung jawab, peduli } \\
\text { (toleransi, gotong royong), santun, } \\
\text { percaya diri, dalam berinteraksi secara } \\
\text { efektif dengan lingkungan sosial dan } \\
\text { alam dalam jangkauan pergaulan dan } \\
\text { keberadaanya. Afektif }\end{array}$ & A \\
\hline KI 3 & $\begin{array}{l}\text { Memahami pengetahuan (faktual, } \\
\text { konseptual, dan prosedural) berdasarkan } \\
\text { rasa ingin tahunya tentang ilmu } \\
\text { pengetahuan, teknologi, seni, budaya } \\
\text { terkait fenomena dan kejadian yang } \\
\text { tampak oleh mata. }\end{array}$ & Kognitif \\
\hline KI 4 & $\begin{array}{l}\text { Mencoba, mengolah, dan menyaji dalam } \\
\text { ranah konkret (menggunakan, mengurai, } \\
\text { merangkai, memodifikasi, dan membuat) } \\
\text { dan ranah abstrak (menulis, membaca, } \\
\text { menghitung, menggambar, dan } \\
\text { mengarang) sesuai dengan yang } \\
\text { dipelajari disekolah dan sumber lainnya } \\
\text { yang sama dalam sudut pandang/teori. }\end{array}$ & Psikomotorik \\
\hline
\end{tabular}

Setiap materi harus mengandung 4 Kompetensi Inti atau boleh salah satunya saja di antara KI 2,3,4. Materi yang belandaskan 4 Kompetensi Inti dapat dikatakan sebagai materi yang sempurna. Dikatakan sempurna karena telah menunjukan adanya Kompetensi Inti yang dijadikan sebagai tolak ukur dalam mencapai tujuan belajar. Hanya saja tingkat keluasan dan kedalaman materi yang diajarkan belum bisa dikatakn sempurna. Untuk mencapai keluasan dan kedalaman materi maka perlu peran seorang guru. Guru memiliki tanggung jawab membantu siswanya belajar agar belajar dirasa

14 Kementrian Agama, Buku Guru, Fikih Madrasah Tsanawiyah VIII, hal 46. 
lebih mudah, lebih terarah, lebih lancar dengan memanfaatkan sumber belajar $^{15}$ dan pengembangan materi pelajaran.

\section{Kompetensi Inti Materi Puasa, Fikih Kelas VIII Madrasah Tsanawiyah}

\begin{tabular}{c|l|c}
\hline No & \multicolumn{1}{|c|}{ Kompetensi Dasar } & Aspek \\
\hline KI 1 & menghayati hikmah ibadah puasa & Spiritual \\
\hline KI 2 & $\begin{array}{l}\text { memiliki sikap simpati dan empati sebagai } \\
\text { ipmlementasi atas pemahaman menganai } \\
\text { hikmah berpuasa }\end{array}$ & Afektif (sikap) \\
\hline KI 3 & menganalisis ketentuan ibadah puasa & $\begin{array}{c}\text { Kognitif } \\
\text { (pengetahuan) }\end{array}$ \\
\hline KI 4 & $\begin{array}{l}\text { mensimulasikan tata cara menjalankan } \\
\text { ibadah puasa }\end{array}$ & $\begin{array}{c}\text { Psikomotorik } \\
\text { (keterampilan) }\end{array}$
\end{tabular}

\section{b. Analisis Materi Puasa Pada Pelajaran Fikih Kelas VIII Madrasah}

\section{Tsanawiyah}

Peta konsep pencapaian materi puasa sebagaimana ketentuan-ketentuan yang terdapat buku cetak siswa berikut ${ }^{16}$ :

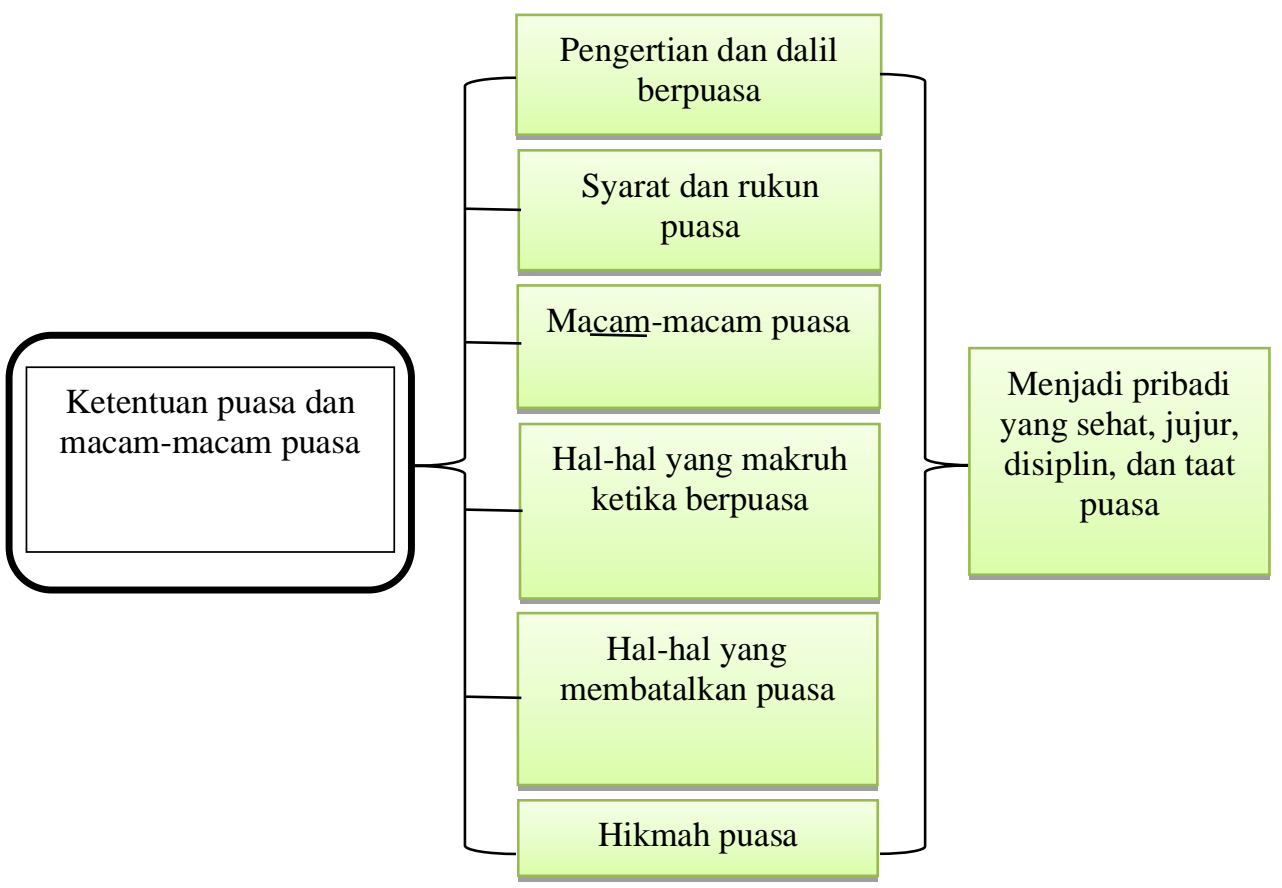

15 M sahran Jailani dan Abdul Hamid, "Pengembangan Sumber Belajar Berbasis Karakter Peserta Didik (Ikhtiar optimalisasi Proses Pembelajaran Pendidi-kan Agama Islam (PAI)), N Nadwa 10, no. 2 (5 Maret 2017): hal 179, https://doi.org/10.21580/nw.2016.10.2.1284.

16 Kementrian Agama, Buku Siswa, Fikih Madrasah Tsanawiyah VIII (Jakarta: Direktorat Pendidikan Madrasah Direktorat Jenderal Pendidikan Islam Kementerian Agama Republik Indonesia, 2015), hal 26. 
Peta diatas memberikan gambaran mengenai materi-materi yang akan disampaikan guru dalam pembelajaran. Dapat dilihat bahwa peta tersebut menunjukan tujuan yang ingin dicapai setelah belajar tentang puasa dan juga menunjukan materi-materi yang akan diajarkan untuk mencapai tujuan tersebut (menjadi sehat, jujur, disiplin, dan taat berpuasa). Penulis merasa materi-materi yang akan diajarkan sudah sangat baik, hanya saja pada apa yang tertulis di dalam buku cetak masihlah kurang luas dan mendalam, mengingat bahwa siswa kelas VIII atau umumnya usia 14 tahun sudah mulai puber dan rasa ingin tahunya meningkat. Jadi, masih perlu dilakukan penambahan dan pengembangan pada pembahasan tentang puasa di kelas VIII Madrasah Tsanawiyah.

\section{c. Aspek Yang Perlu Diperhatikan Dalam Pengembangan Materi}

Terdapat beberapa aspek yang harus diperhatikan saat melakukan perevisian atau pengembangan materi pembelajaran, yaitu Fakta, Konsep, Prosedur, dan Perinsip. Keempat aspek ini menjadi landasan dalam mengembangkan materi. Dalam pengembangannya empat aspek tersebut harus mencerminkan keluasan dan kedalaman, serta besifat distingtif (beda/khusus), fungsional, bernilai, dan mudah digunakan. ${ }^{17}$

1. Fakta maksudnya adalah materinya dapat di buktikan lewat sejarah, penelitian, dan objektif

2. Konsep adalah berupa pengertian, hakikat, definisi (berdasarkan fakta)

3. Prinsip adalah berupa dalil, landasan, rumus, paradigma

4. Prosedur adalah berupa Langkah kerja atau berupa langkah-langkah untuk memahami.

\begin{tabular}{c|l}
\hline Aspek & \multicolumn{3}{|c}{ Pengertian } \\
\hline $\begin{array}{c}\text { Distingtif } \\
\text { (berbeda) }\end{array}$ & $\begin{array}{l}\text { Adanya perbedaan yang terlihat antara materi sebelum } \\
\text { dikembangkan dan dan sesudah dikembangkan. } \\
\text { Contoh: }\end{array}$ \\
\hline Fungsional & Pengembangan materi yang dilakukan memiliki \\
17 Karwadi, Kuliah Pengembangan Materi Pendidikan Islam (Kampus UIN SUKA \\
yakarta, 2020).
\end{tabular}




\begin{tabular}{c|l}
\hline & banyak fungsi atau serbaguna dalam banyak hal. \\
\hline & \begin{tabular}{l} 
Novelty: akan menjadi benilai katika bersifat baru atau \\
mutakhir. Guru harus mengikuti kemajuan \\
perkembangan ilmu pengetahuan sesuai spesialis \\
keilmuannya. \\
Proximity: materi atau isi yang akan disampaikan \\
baiknya sesuai dengan apa yang menjadi pengalaman \\
siswa mernilai \\
Conflict: penyajian materi harusnya bersifat menarik \\
sehingga muncul perubahan atau stimulus pada siswa. \\
Materi yang dikemas menarik akan membuat siswa \\
lebih antusias saat menerima materi. \\
Humor: adanya efek humor atau candaan dalam \\
materi untuk menghilangkan kejenuhan pada siswa. ${ }^{18}$ \\
\hline 1. Tidak melenceng dari tujuan yang akan dicapai \\
2. Lebih sederhana dan lebih berisi \\
3. Desain materi bisa berupa visual atau audio visual \\
4. Pengorganisasian materi \\
5. Dikemas secara menarik ${ }^{19}$
\end{tabular} \\
\hline
\end{tabular}

Syarat yang harus di perhatikan oleh guru dalam mengembangkan materi, yaitu harus berdasarkan kedua pembahasan diatas. Empat aspek yaitu fakta, konsep, prisip, dan prosedur, yang kemudian empat aspek tersebut harus mencakup hal-hal berikut: Distingtif (berbeda/bede dari yang sebelumnya), fungsional, bernilai, dan mudah digunakan. Jadi sebuah materi yang dikembangkan harus memiliki perbedaan dengan materi yang belum dikembangkan, selanjutnya bisa lebih fungsional, mamiliki nilai salah satunya mengandung nilai humor, dan yang terakhir mudah digunakan, karena untuk apa dikembangkan jika hasilnya lebih susah, digunakan, susah diajarkan, ataupun susah dipahami. hal 150-151.

18 Wina Sanjaya, Perencanaan dan Desai Sistem Pembelajaran (Jakarta: Kencana, 2017),

19 Sanjaya, hal 151-153. 
d. Pengembangan Materi Fikih Madrasah Tsanawiyah Kelas VIII Tentang Indahnya Berpuasa

\begin{tabular}{|c|c|}
\hline Aspek & Materi \\
\hline Fakta & $\begin{array}{l}\text { a. Perintah puasa dalam Syariat Islam } \\
\text { b. Larangan berpuasa dalam Syariat islam } \\
\text { c. Puasa adalah rukun Islam } \\
\text { d. Al-Qur'an dan hadis sebagai dasar }\end{array}$ \\
\hline Konsep & $\begin{array}{l}\text { a. Pengertian puasa yang dijelaskan dalam Al-Qur'an } \\
\text { dan hadis } \\
\text { b. Ketentuan berpuasa dalam hukum Islam } \\
\text { c. Macam-macam puasa } \\
\text { d. Evaluasi penilaian menggunakan pilihan ganda, isian } \\
\text { singkat, dan tugas-tugas. }\end{array}$ \\
\hline Prisip & $\begin{array}{l}\text { a. QS. Al-Baqarah (183-187) QS. Al-Baqarah (196). QS. } \\
\text { Yunus (5), QS. Al-Hajj (29), QS. Al-Maidah (89), QS. } \\
\text { Al-Mujadilah (3-4). QS. An-Nisa (92), dan hadis } \\
\text { sahih yang menjekaskan tentang puasa. } \\
\text { b. Puasa dapat membentuk manusia yang bertaqwa } \\
\text { c. Puasa mendapat balasan ampunan dari Allah }\end{array}$ \\
\hline Prosedur & $\begin{array}{l}\text { a. Untuk dapat menjalankan ibadah puasa dengan baik, } \\
\text { maka harus mengetahui pengertian berpuasa, serta } \\
\text { syarat dan rukun berpuasa, dan mengetahui hal-hal } \\
\text { yang membatalkan berpuasa. } \\
\text { b. Untuk mendapatkan hikmah puasa, maka perlu juga } \\
\text { mengetahui hal-hal sunah dalam berpuasa, serta } \\
\text { hal-hal yang makruh dilakukan saat berpuasa. }\end{array}$ \\
\hline
\end{tabular}

Tabel di atas barulah memaparkan materi puasa berdasarkan buku cetak atau buku siswa dan belum dilakukan pengembangan materi. Pada tabel berikutnya barulah memaparkan pengembangan materi. Pengembangan materi yang dilakukan berupa revisi materi yang sebelumnya, penambahan ataupun pengurangan materi yang sudah ada dengan tujuan setelah dirvisi, maka materi yang diajarkan akan lebih mudah dipahami, berbeda dari materi sebelumnya, serta lebih mendalam lagi. Penulisannya berupa penambahan poin-poin materi baru yang dimasukkan dalam tabel berikut, serta tertulis tebal dan miring. 


\begin{tabular}{|c|c|}
\hline Aspek & $\begin{array}{r}\text { Materi } \\
\end{array}$ \\
\hline Fakta & $\begin{array}{l}\text { a. Perintah puasa dalam Syari'at Islam } \\
\text { b. Larangan berpuasa (waktu-waktu yang dilarang } \\
\text { berpuasa) dalam Syariat islam } \\
\text { c. Puasa adalah rukun Islam } \\
\text { d. Al-Qur'an dan hadis sebagai dasar } \\
\text { e. Puasa membuat tubuh menjadi sehat berdasarkan } \\
\text { penjelasan ilmu kedokteran } \\
\text { f. Larangan berpuasa karena alasan kesehatan } \\
\text { menurut ilmu kedokteran } \\
\text { g. Hukum puasa dengan niat untuk diet (penjelasan } \\
\text { menurut syari'at islam) serta perbedaan puasa dan } \\
\text { diet menurut ilmu kesehatan. } \\
\text { h. Tips kedokteran agar tidak loyo/lesu saat berpuasa } \\
\text { i. Makanan dan minuman yang di sarankan untuk } \\
\text { dikonsumsi saat berbuka dan sahur } \\
\text { j. Makanan yang sebaiknya dikonsumsi terlebih } \\
\text { dahulu saat berbuka puasa agar tidak sakit perut. } \\
\text { k. Larangan tidur setelah makan sahur karena tidak } \\
\text { baik menurut ilmu kesehatan/kedokteran. }\end{array}$ \\
\hline Konsep & $\begin{array}{l}\text { a. Pengertian puasa yang dijelaskan dalam Al-Qur'an } \\
\text { dan hadis } \\
\text { b. Ketentuan berpuasa dalam hukum Islam } \\
\text { c. Macam-macam puasa } \\
\text { d. Evaluasi penilaian menggunakan pilihan ganda, isian } \\
\text { singkat, dan tugas-tugas. } \\
\text { e. Ciri-ciri orang yang dilarang berpuasa menurut } \\
\text { ilmu kedokteran } \\
\text { f. Cara meraih hikmah puasa } \\
\text { g. Contoh sikap yang ditunjukan orang yang telah } \\
\text { mendapatkan kebaikan/hikmah puasa }\end{array}$ \\
\hline Prisip & $\begin{array}{l}\text { a. QS. Al-Baqarah (183-187) QS. Al-Baqarah (196). QS. } \\
\text { Yunus (5), QS. Al-Hajj (29), QS. Al-Maidah (89), QS. } \\
\text { Al-Mujadilah (3-4). QS. An-Nisa (92), termasuk } \\
\text { semua dalil Al-Quran yang menjelaskan hukum } \\
\text { puasa dan hadis sahih yang menjekaskan tentang } \\
\text { puasa. } \\
\text { b. Puasa dapat membentuk manusia yang bertaqwa } \\
\text { c. Puasa mendapat balasan ampunan dari Allah } \\
\text { d. Dalil Al-Qur'an dan hadis yang mejelaskan } \\
\text { hukuman meninggalkan puasa wajib. contoh (hadis } \\
\text { riwayat Nasa'i dalam as-sunan al-kubra, no 3273; } \\
\text { Ibnu Hibban; Ibnu Khuzaimah; al-Baihaqi. 4/216; } \\
\text { al-hakim, no. 1568; ath-Thabrani dalam Mu'jamul } \\
\text { Kabir. Disahihkan oleh al-hakim, adz-Dzahabi, } \\
\text { al-haitsami. Lihat: al-jami' li Ahkamis Shiyam, }\end{array}$ \\
\hline
\end{tabular}




\begin{tabular}{l|l}
\hline e. $\begin{array}{l}\text { 1/60). } \\
\text { Penjelasan mengenai pahala anak-anak yang } \\
\text { melakukan puasa ramadhan (wajib) tetapi belum } \\
\text { baligh. }\end{array}$ \\
\hline a. $\begin{array}{l}\text { Untuk dapat menjalankan ibadah puasa dengan baik, } \\
\text { maka harus mengetahui pengertian berpuasa, serta } \\
\text { syarat dan rukun berpuasa, dan mengetahui hal-hal } \\
\text { yang membatalkan berpuasa. }\end{array}$ \\
b. $\begin{array}{l}\text { Untuk mendapatkan hikmah puasa, maka perlu juga } \\
\text { mengetahui hal-hal sunah dalam berpuasa, serta } \\
\text { hal-hal yang makruh dilakukan saat berpuasa. } \\
\text { Tahapan atau tata cara melatih puasa untuk anak } \\
\text { dibawar umur atau yang belum baligh. } \\
\text { Berbagi kebaikan puasa dengan cara mengajak } \\
\text { orang lain yang belum puasa dengan ajakan yang } \\
\text { santun dan lemah lembut agar mau menjalankan } \\
\text { ibadah puasa wajib. }\end{array}$ \\
\hline
\end{tabular}

Poin-poin yang dituliskan pada tabel diatas merupakan sebuah tambahan untuk memperdalam dan memperluas cakupan materi yang diajarkan. Materi yang ada pada buku cetak siswa secara umum masihlah menjelaskan tentang puasa dari sudut pandang Al-Qur'an dan hadis, sehingganya pelru juga penjelasan mengenai materi puasa dari segi kesehatan atau ilmu kedokteran. Penjelasan mengenai puasa yang menjadikan fisik menjadi lebih sehat berdasarkan hasil penelitian dan ilmu kedokteran sangat membantu memotivasi para siswa untuk menjalankan ibadah puasa wajib dan juga puasa sunnah. Selanjutnya tak hanya sampai disitu untuk memperdalam materi puasa juga perlu penjelasan mengenai perbedaan diet dan puasa baik dari sudut pandang syari'at islam ataupun ilmu kedokteran.

Pada buku cetak siswa juga telah dijelaskan mengenai larangan melakukan puasa pada waktu-waktu tertentu, dan juga orang-orang yang boleh tidak berpuasa ramadhan (wajib) tetapi harus mengganti puasanya seperti, orang yang sedang sakit, wanita yang sedang haid, dan orang yang sedang dalam perjalanan. Kemudian juga dijelaskan orang-orang yang boleh tidak melakukan puasa ramadhan (wajib) tetapi harus membayar fidyah (denda) seperti, orang tua renta, wanita hamil, sedang menyusui anak, dan sebagainya. Penjelasan mengenai orang-orang yang dibolehkan tidak 
berpuasa tersebut kirannya juga perlu disertai dengan penjelasan dari sudut pandang ilmu kedokteran, atau minimal ciri-ciri orang yang dilarang puasa menurut ilmu kesehatan/kedokteran.

Pada tingkatan kelas VIII atau kurang lebih usia 14 tahun, siswa sudah menjalankan ibadah puasa, baik wajib atau sunnah. Sehinnga perluasan materi juga perlu mencakup tentang makanan dan minuman yang baik dikonsumsi saat sahur dan berbuka, atau lebih spesifik lagi makanan dan minuman apa yang sebaiknya dikonsumsi terlebih dahulu saat bebuka puasa. Dan juga tips ala dokter agar tidak loyo/lesu saat menjalankan ibadah puasa. Bagi siswa yang mungkin belum terbiasa bangun pagi untuk makan sahur, pasti sangat merasa ngantuk karena harus bangun jam 3 pagi atau sebelum subuh, hal inilah yang biasanya membuat mereka tidur lagi setelah makan sahur, padahal tidur setelah makan tidak dianjurkan dari segi kesehatan. Oleh karenanya materi seperti ini juga perlu disampaikan oleh guru pada saat mengajar agar wawasan yang diperoleh siswa menjadi lebih luas.

Penulis merasa masih banyak materi yang perlu ditambahkan dalam pembahasan mengenai puasa ini. Pada buku cetak siswa, fikih kelas VIII hanya di sebutkan apa-apa saja hikmah yang diperoleh dari puasa. ${ }^{20}$ Kurangnya adalah materi tentang cara memperoleh/meraih hikmah puasa belum dijelaskan dalam buku cetak siswa. Apabila guru tidak memiliki inisiatif untuk menjelaskan materi ini, dan hanya berpatokan kepada buku cetak saja, maka siswa akan merasa kurang puas dengan pembelajaran yang di adakan oleh gurunya. Sehingga selain menunjukan hikmah puasa, kirannya juga perlu menunjukan cara meraih hikmah puasa, serta ciri-ciri orang yang telah memperoleh kebaikan/hikmah puasa, agar siswa dapat mengamati orang yang memiliki ciri-ciri tersebut dan menggali informasi dari orang tersebut tentang bagaimana cara memperoleh hikmah puasa.

Pada pembelajaran fikih juga perlu penekanan agar siswa mau dan terbiasa menjalankan ibadan puasa, terutama puasa wajib pada bulan ramadhan. Sehingga ketika guru menjelaskan tentang materi puasa, selain 
menjelaskan bahwa puasa itu wajib, juga perlu menjelaskan ancaman bagi orang-orang yang meninggalkan puasa, sebagai contoh (hadis riwayat Nasa’i dalam as-sunan al-kubra, no 3273; Ibnu Hibban; Ibnu Khuzaimah; al-Baihaqi. 4/216; al-hakim, no. 1568; ath-Thabrani dalam Mu’jamul Kabir. Disahihkan oleh al-hakim, adz-Dzahabi, al-haitsami. Lihat: al-jami’ li Ahkamis Shiyam, 1/60). Yang menjelaskan tentang orang-orang yang tidak puasa, atau yang berbuka (membatalkan puasa) sebelum waktunya.

Pengembangan materi sangat diperlukan demi keluasan dan kedalaman materi yang diajarkan. Referensi atau sudut pandang yang digunakan haruslah ditambah, guru tidak bisa berpatokan hanya pada buku cetak saja karena saat ini internet telah memberikan kemudahan untuk mengakses referensi-referensi yang dibutukkan. Kejadian-kejadian yang terjadi dalam lingkungan sehari-hari juga bisa dikaitkan dengan materi yang diajarkan. Materi yang memiliki beragam referensi akan lebih mendalam dan mudah dipahami, baik itu mudah bagi guru untuk menjelaskan dan juga mudah bagi siswa untuk memahaminya.

\section{Kesimpulan}

Melakukan pengembangan materi pada setiap mata pelajaran adalah suatu keharusan bagi guru. Buku cetak yag telah ada tidak menjamin bisa dipahami siswa dengan begitu saja, sehingga perlu campur tangan guru untuk mengotak-atik materi yang ada didalam buku tersebut, Hal ini dimaksudkan agar para siswa tidak gagap terhadap perkembangan IPTEK dan mampu mengimbanginya dengan ilmu agama yang telah dipelajarinya. Dengan melakukan perevisian dan pengembangan pada materi pelajaran, maka diharapkan materi tersebut bisa berbeda dari yang sebelumnya, semakin berbobot, fungsional dan mudah untuk dipahami bagi guru maupun siswa. Syarat selanjutnya adalah pengembangan materi pelajaran harus berlandaskankan empat aspek yaitu pertama fakta, materi yang disampaikan haruslah berupa fakta yang ada baik itu hasil penelitian atau dalil dari

20 Kementrian Agama, Buku Siswa, Fikih Madrasah Tsanawiyah VIII, hal 34. 
Al-Qur'an dan juga fakta-fakta yang lainnya yang bersifat objektif. Kedua prinsip, adanya landasan yang dipakai berupa dalil, atau landasan-landasan yang lainnya. Ketiga konsep. Yang selanjutnya berupa prosedur kerjanya. 


\section{DAFTAR PUSTAKA}

Basuki. Pengembangan Model Pembelajaran Membaca Dengan Pelabelan Objek Sekitar (POS) Untuk Murid Taman Kanak-kanak. Sleman: Deepublish, 2015.

Churri, Mohamad Ainul, dan Yudha Anggana Agung. "Pengembangan Materi Dan Media Pembelajaran Mata Pelajaran Dasar Kompetensi Kejuruan Teknik Audio Video Untuk Smk Negeri 7 Surabaya” 2 (2013): 7.

Jailani, M sahran, dan Abdul Hamid. "Pengembangan Sumber Belajar Berbasis Karakter Peserta Didik (Ikhtiar optimalisasi Proses Pembelajaran Pendidi-kan Agama Islam (PAI)).” Nadwa 10, no. 2 (5 Maret 2017): 175. https://doi.org/10.21580/nw.2016.10.2.1284.

Karwadi. Kuliah Pengembangan Materi Pendidikan Islam. Kampus UIN SUKA Yogyakarta, 2020.

Kementrian Agama. Buku Guru, Fikih Madrasah Tsanawiyah VIII. Jakarta: Direktorat Pendidikan Madrasah Direktorat Jenderal Pendidikan Islam Kementerian Agama Republik Indonesia, 2015.

. Buku Siswa, Fikih Madrasah Tsanawiyah VIII. Jakarta: Direktorat Pendidikan Madrasah Direktorat Jenderal Pendidikan Islam Kementerian Agama Republik Indonesia, 2015.

M Zaidi Abdad. “Analisis dan Pemetaan Pemikiran Fikih Moderat di Timur Tengah dan Relasinya dengan Gerakan Fikih Formalis.” ESENSIA: Jurnal Ilmu-Ilmu Ushuluddin Vol 12, No 1 (2011) https://doi.org/10.14421/esensia.v12i1.701

M. Shabir U. "Relevansi Hukuman Takzir dalam Fikih Dengan Hukuman Sebagai Alat Pendidikan” Lentera Pendidikan : Jurnal Ilmu Tarbiyah dan Keguruan, Vol 11, No 2 (2008) https://doi.org/10.24252/lp.2008v11n2a6

Mustafa, M. (2008, August 15). Elaborasi dan Eksplorasi Pemahaman Fikih Kontemporer. Hunafa: Jurnal Studia Islamika, 5(2), 177-188. https://doi.org/https://doi.org/10.24239/jsi.v5i2.164.177-188

Muthohar, Yasin. 2018. "Kewajiban Adanya Kepemimpinan Politik Dalam Perspektif Fikih”. Jurnal Kajian Peradaban Islam 1 (1), 35-49. https://doi.org/https://doi.org/10.47076/jkpis.v1i1.12.

Natsir, M. "Pengembangan Pembelajaran Fikih Kelas X Madrasah Aliyah Dalam Model Dick \& Carey.” Jurnal Pendidikan Agama Islam (Journal of Islamic 
Education Studies) 5, no. 1 (2 November 2017): 44. https://doi.org/10.15642/jpai.2017.5.1.44-67.

Parnawi, Afi. Psikologi Belajar. Sleman: Deepublish, 2019.

Prastowo, Andi. Menyusun Rencana Pelaksanaan Pembelajaran (Rpp) Tematik Terpadu Implementasi Kurikulum 2013 Untuk Sd/Mi. Cetakan ke-2. Jakarta: Kencana, 2017.

Samidi K. "Konsep Al-Ghuslu dalam Kitab Fiqih Manhaji” Analisa: Journal of Social and Religion, Vol 17, No 1 (2010) https://doi.org/10.18784/analisa.v17i1.116

Sanjaya, Wina. Perencanaan dan Desai Sistem Pembelajaran. Jakarta: Kencana, 2017.

Saputra, Henry Januar, dan Nur Isti Faizah. "Pengembangan Bahan Ajar Untuk Menumbuhkan Nilai Karakter Peduli Lingkungan Pada Siswa Kelas Iv Sekolah Dasar.” Profesi Pendidikan Dasar 1, no. 1 (8 Januari 2018): 57. https://doi.org/10.23917/ppd.v1i1.3956.

Susandi. "Pengembangan Bahan Ajar Fiqih Berbasis Multimedia Menggunakan Aplikasi Autiplay Studio 8.” Jurnal Penelitian Ipteks volume 4, no. 2 (2019).

Sutrisno, dan Muhyidin Albarobis. Pendidikan Islam Berbasis Problem Sosial. Yogyakarta: Ar-Ruzz Media, 2012.

Taufik, Ermaniatu. N, M. "Pengembangan Bahan Ajar Cetak Berbasis Penilaian Kinerja Sebagai Sumber Belajar Bagi Siswa Sd Kelas Vi.” School Education Journal Pgsd Fip Unimed 7, no. 3 (20 Juni 2017): 285-95. https://doi.org/10.24114/sejpgsd.v7i3.9251.

Windura, Sutanto. Shortcut to genius: (belajar lebih sedikit, tahu lebih banyak, dan bebas stres!). Jakarta: PT Gramedia, 2013.

Zain, Muhammad. "Pengembangan Strategi Pembelajaran Dan Pemilihan Bahan Ajar.” Inspiratif Pendidikan 6, no. 1 (1 Juni 2017): 172. https://doi.org/10.24252/ip.v6i1.4925. 
